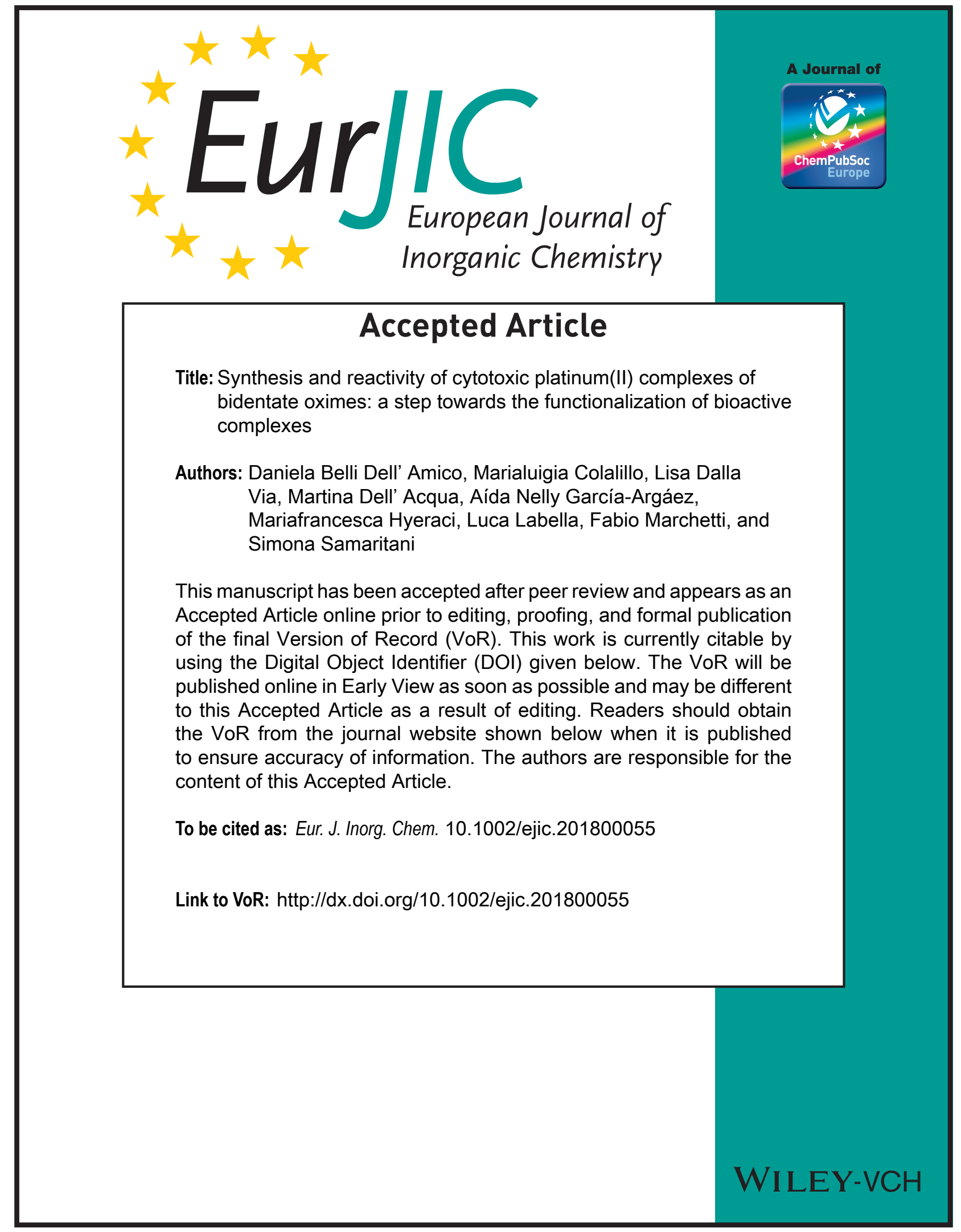




\title{
Synthesis and reactivity of cytotoxic platinum(II) complexes of bidentate oximes: a step towards the functionalization of bioactive complexes.
}

\author{
Daniela Belli Dell' Amico, ${ }^{[a]}$ Marialuigia Colalillo, ${ }^{[a]}$ Lisa Dalla Via,${ }^{[b]}$ Martina Dell' Acqua ${ }^{[a]}$ Aída N. \\ García-Argáez, ${ }^{[b]}$ Mariafrancesca Hyeraci, ${ }^{[b]}$ Luca Labella, ${ }^{[a]}$ Fabio Marchetti ${ }^{[a]}$ and Simona \\ Samaritani*[a]
}

\begin{abstract}
Two new complexes of platinum(II) bearing triphenylphosphine and bidentate oxime ligands $\left[\mathrm{Pt}(\mathrm{Cl})\left(\mathrm{PPh}_{3}\right)\left\{\left(\mathrm{K}^{2}-\right.\right.\right.$ $\left.\mathrm{N}, \mathrm{O})-\left[1\left(\mathrm{C}(\mathrm{R})=\mathrm{N}(\mathrm{OH})-2(\mathrm{O}) \mathrm{C}_{10} \mathrm{H}_{6}\right]\right\}\right](\mathrm{R}=\mathrm{H}, \mathrm{Me})$ were synthesized in good yields starting from trans-[PtCl$\left.(\mu-\mathrm{Cl})\left(\mathrm{PPh}_{3}\right)\right]_{2}$. The structure of $\left[\mathrm{Pt}(\mathrm{Cl})\left(\mathrm{PPh}_{3}\right)\left\{\left(\mathrm{K}^{2}-\mathrm{N}, \mathrm{O}\right)-\left[1\left(\mathrm{CH}=\mathrm{N}(\mathrm{OH})-2(\mathrm{O}) \mathrm{C}_{10} \mathrm{H}_{6}\right]\right\}\right]\right.$ was determined by single crystal $\mathrm{X}$-ray diffraction. Both complexes showed good antiproliferative properties in vitro against HeLa, A2780 and A2780cis cancer cell lines. They react cleanly with alkylating agents in the presence of aqueous bases under phase transfer catalysis conditions, affording the corresponding $\mathrm{O}$-alkylation products $\left[\mathrm{Pt}(\mathrm{Cl})\left(\mathrm{PPh}_{3}\right)\left\{\left(\mathrm{K}^{2}-\mathrm{N}, \mathrm{O}\right)-\left[1\left(\mathrm{HC}=\mathrm{N}(\mathrm{OR})-2(\mathrm{O}) \mathrm{C}_{10} \mathrm{H}_{6}\right]\right\}\right] \quad\left(\mathrm{R}^{\prime}=\mathrm{CH}_{2} \mathrm{CH}_{2} \mathrm{Cl}\right.\right.$, $\left.\mathrm{CH}_{2} \mathrm{Ph},\left(\mathrm{CH}_{2}\right)_{4} \mathrm{Br}\right)$ in good yields.
\end{abstract}

\section{Introduction}

After the discover and the approval of cisplatin ${ }^{[1]}$ as powerful anticancer agent, every year hundreds of new platinum complexes are prepared and tested, in the continuous and challenging search for less toxic and more specific drugs. In this context, non-conventional analogues of cisplatin able to circumvent resistance and new synthetic approaches addressed to drug delivery are important research topics. ${ }^{[2]}$ In this view, the presence of reactive functional groups can be of great help. Among unconventional platinum derivatives, those containing phosphane ligands ${ }^{[3]}$ have often shown an interesting ability to circumvent cisplatin resistance, with mechanisms significantly different from cisplatin mode of action ${ }^{[3 \mathrm{~d}, \mathrm{~g}, \mathrm{j}, 1]}$ and with the phosphane ligand playing a crucial role in the intracellular drug uptake. ${ }^{[3 k, l]}$ In this context, we have recently been interested in oxime derivatives. ${ }^{[3 a]}$ In fact, the known acidity of oxime hydroxyl

[a] Dipartimento di Chimica e Chimica Industriale and CIRCC Università di Pisa

via Giuseppe Moruzzi 13, Pisa I-56124 E-mail: simona.samaritani@unipi.it https://people.unipi.it/simona samaritani/

[b] Dipartimento di Scienze del Farmaco Università degli Studi di Padova Via F. Marzolo 5, Padova, I-35131 residue, which is greatly enhanced upon coordination to metals, ${ }^{[4]}$ can be exploited both for the formation of non-bonding interactions and for synthetic modifications of the complexes. It is known, indeed, that some platinum oxime complexes possess interesting antiproliferative properties. ${ }^{[5]}$ In our previous study ${ }^{[3 a]}$ concerning monodentate $\left[\mathrm{PtCl}_{2}\left(\mathrm{PPh}_{3}\right)\right.$ (oxime)] derivatives, we had observed an interesting reactivity of these systems with aqueous bases under phase transfer catalysis conditions, leading to the formation of rare dinuclear oximate complexes. ${ }^{[3 a]}$ Nevertheless, the scarce water solubility of the prepared compounds and their instability in DMSO had prevented us from testing them in vitro as antiproliferative agents. In this work, we report the synthesis and the in vitro antiproliferative properties of two stable, $\mathrm{PPh}_{3}$, oxime $\mathrm{Pt}(\mathrm{II})$ chelated complexes and we show that the oxime hydroxyl group can be conveniently exploited to functionalize the compounds.

\section{Results and Discussion}

Synthesis of the complexes

Bidentate oxime ligands 1-2 (Figure 1) used in this work were prepared starting from the corresponding 2hydroxyarylcarbonylic compounds, according to reported procedures. $^{[6]}$<smiles>C/C(=N\O)c1ccc2ccccc2c1O</smiles>

Figure 1. Bidentate 2-hydroxyarylald- and ketoximes used in this work 
solution, starting from trans- $\left[\mathrm{PtCl}(\mu-\mathrm{Cl})\left(\mathrm{PPh}_{3}\right)\right]_{2}{ }^{[7]}$ and following the reaction by ${ }^{31} \mathrm{P}-\mathrm{NMR}$. As expected, the bridge-splitting reaction is initially guided by the strong trans effect exerted by the $\mathrm{PPh}_{3}$ group, leading to the formation of a monodentate trans(Z) kinetic intermediate (Scheme 1). At variance with the analogous monodentate systems we studied earlier, ${ }^{[3 a]}$ the formation of the kinetic intermediate was not followed by any isomerization in solution. A slow elimination of $\mathrm{HCl}$ was instead observed, leading to single chelation products 3-4, which were recovered by the usual work-up procedures and characterized by IR (ATR), ${ }^{1} \mathrm{H}-,{ }^{31} \mathrm{P}-,{ }^{13} \mathrm{C}$ - and ${ }^{195} \mathrm{Pt}$-NMR (Figures SI1-SI8). Since the elimination of gaseous $\mathrm{HCl}$ (Scheme 1) took up to two weeks, with maximum isolated yields ranging from 30 to $47 \%$, the syntheses were repeated in the presence of silver acetate.

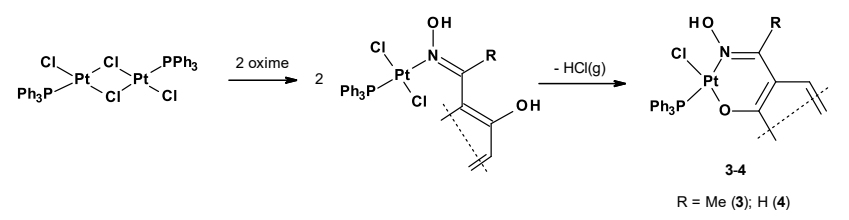

Scheme 1. Synthesis of chelated complexes 3 and $\mathbf{4}$

In fact, while silver ion could facilitate the intermediate dehalogenation, the presence of acetate ion could help the deprotonation of phenolic residue on the oxime ligand. In these conditions the reactions were much faster $(2 \mathrm{~h})$ and the isolated yield of the bidentate complexes could be improved (70-89\%).

It is worth to note that deprotonation of the phenolic function was selective and the desired chelated complex was the only product observed. No deprotonation of oxime groups by silver acetate was observed in our system at variance with previous reports. ${ }^{[8]}$ Complexes 3-4 are soluble in common chlorinated solvents and scarcely soluble in water or ethanol. They are soluble in DMSO and their stability was checked by ${ }^{31} \mathrm{P}$ NMR in a $20 \mathrm{mM}$ DMSO solution containing $\mathrm{H}_{2} \mathrm{O}$ (5 vol.-\%). It is known, in fact, that, in some cases, the presence of water can favor the reactivity of platinum substrates toward DMSO. ${ }^{[9]}$ In these conditions the solutions were stable up to $24 \mathrm{~h}$ at r.t. (Figures SI9-SI10).Stock solutions of the complexes for the in vitro assays were thus prepared in DMSO and stocked at $-18^{\circ} \mathrm{C}$.

For complex 4 the structure was confirmed by single crystal Xray diffraction.

The structure of complex 4 is represented in Figure 2, while the most significant bond lengths and angles are reported in Table 1 Coordination around platinum center is square planar, with small deviations from ideal bond angles. The oxime chelates the metal through nitrogen atom and the deprotonated phenolic group on position 2 of the aromatic moiety. The platinum coordination sphere is completed by a $\mathrm{PPh}_{3}$, in trans to the oxime nitrogen atom, and by a chloride ion. Pt-O and Pt-N bond lengths can be compared with those in the complex $\left[\mathrm{Pt}\left(\mathrm{o}-\mathrm{OC}_{6} \mathrm{H}_{4} \mathrm{CH}=\mathrm{NOH}\right)_{2}\right]^{[10]}$. $\mathrm{Pt}-\mathrm{O}$ bond distance in $4(1.981(3) \AA)$ is quite close to the one reported by Pombeiro et al. $(1.978(5) \AA)$, while Pt-N bond in 4 $(2.032(3) \AA)$ is, as expected, slightly longer $(2.063(4) \AA$ vs.
1.974(6) $\AA$ ), due to the presence of the phosphine ligand in trans position.

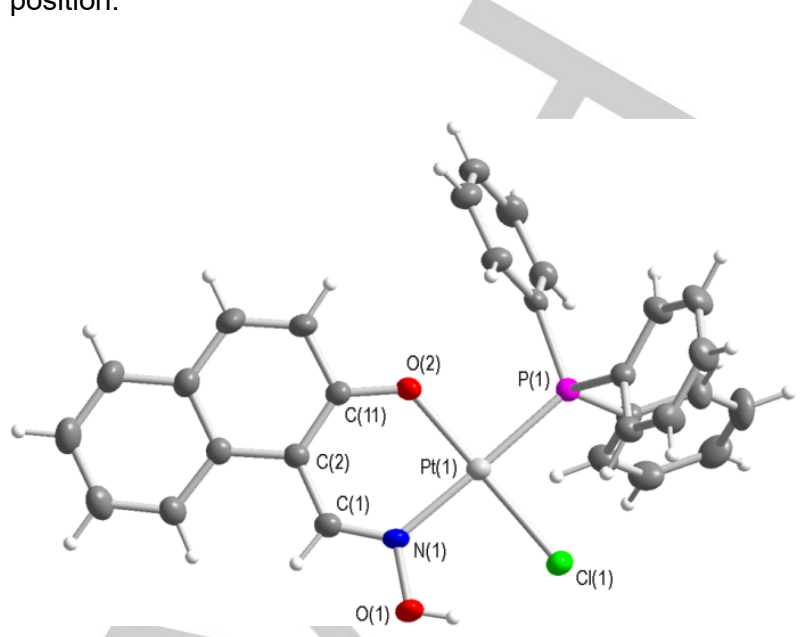

Figure 2. Molecular structure of complex 4

Table 1. Bond lengths $[\AA]$ and angles $\left[^{\circ}\right]$ for complex 4 .

\begin{tabular}{llll}
\hline \multicolumn{3}{c}{ Bond lengths $[\AA]$} & \multicolumn{2}{c}{ Bond angles $\left[^{\circ}\right]$} \\
\hline $\mathrm{Pt}(1)-\mathrm{O}(2)$ & $1.981(3)$ & $\mathrm{O}(2)-\mathrm{Pt}(1)-\mathrm{N}(1)$ & $89.23(11)$ \\
$\mathrm{Pt}(1)-\mathrm{N}(1)$ & $2.032(3)$ & $\mathrm{O}(2)-\mathrm{Pt}(1)-\mathrm{P}(1)$ & $89.23(7)$ \\
$\mathrm{Pt}(1)-\mathrm{P}(1)$ & $2.2488(9)$ & $\mathrm{N}(1)-\mathrm{Pt}(1)-\mathrm{P}(1)$ & $178.45(8)$ \\
$\mathrm{Pt}(1)-\mathrm{Cl}(1)$ & $2.3086(10)$ & $\mathrm{O}(2)-\mathrm{Pt}(1)-\mathrm{Cl}(1)$ & $179.60(9)$ \\
$\mathrm{N}(1)-\mathrm{C}(1)$ & $1.290(5)$ & $\mathrm{N}(1)-\mathrm{Pt}(1)-\mathrm{Cl}(1)$ & $90.68(8)$ \\
$\mathrm{N}(1)-\mathrm{O}(1)$ & $1.393(4)$ & $\mathrm{P}(1)-\mathrm{Pt}(1)-\mathrm{Cl}(1)$ & $90.86(4)$ \\
& & $\mathrm{C}(1)-\mathrm{N}(1)-\mathrm{O}(1)$ & $112.1(3)$ \\
& & $\mathrm{C}(1)-\mathrm{N}(1)-\mathrm{Pt}(1)$ & $127.6(2)$ \\
& & $\mathrm{O}(1)-\mathrm{N}(1)-\mathrm{Pt}(1)$ & $120.3(2)$ \\
\hline
\end{tabular}

\section{Reactivity}

In our previous study ${ }^{[3 a]}$ concerning platinum complexes of monodentate oximes we found that aqueous bases, under phase transfer reaction conditions, deprotonate oxime hydroxyl group, affording rare dinuclear derivatives, where two oximate ligands bridge two platinum centres in a "head to tail" coordination mode (Scheme 2).

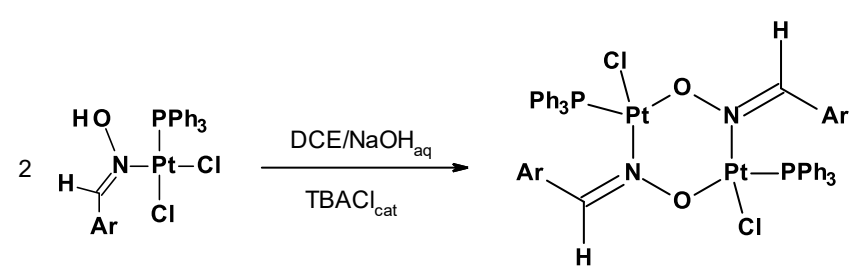

Scheme 2. Reactivity of complexes of monodentate oxime with aqueous bases 
Complex $\mathbf{4}$ was tested for its reactivity in the same conditions. In a typical experiment, 4 was dissolved in 1,2-dichloroethane and the resulting solution was treated with an aqueous $\mathrm{NaOH}$, in the presence of $5 \%$ of tetrabutyl ammonium chloride. The reaction progress was checked by ${ }^{31} \mathrm{P}-\mathrm{NMR}$ on samples taken from the organic phase at different time spans. The spectroscopic analyses showed the gradual disappearing of the signal of $\mathbf{4}$ (6.38ppm, $\left.{ }^{1} \mathrm{JP}_{\mathrm{P}-\mathrm{Pt}}=3821 \mathrm{~Hz}\right)$, in favor of a new one at $6.01 \mathrm{ppm}$ $\left({ }^{1} \mathrm{JP}-\mathrm{Pt}=3807 \mathrm{~Hz}\right)$. The conversion was complete in $24 \mathrm{~h}$ at $25^{\circ} \mathrm{C}$ and a new, single product (5) was recovered from the organic phase after the usual work-up procedures. This complex was characterized spectroscopically. Unexpectedly, collected data showed that no dinuclear derivative had formed, but O-alkylation by the solvent had occurred (Scheme 3 ).

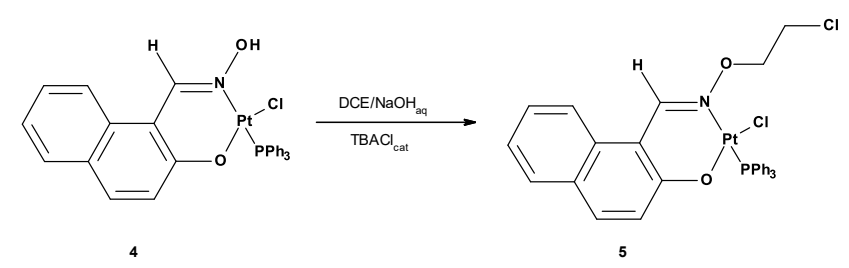

Scheme 3. O-alkylation of complex 4 by 1,2-DCE

Alkylation of the oxime hydroxyl residue was evident in the ${ }^{1} \mathrm{H}$ NMR spectrum of isolated (53\%) $\mathbf{5}$, where oxime $\mathrm{OH}$ singlet at $10.53 \mathrm{ppm}$ was absent and two triplet signals were observed at 4.70 and $3.82 \mathrm{ppm}$, both accounting for two hydrogen atoms and attributable to $\mathrm{OCH}_{2}$ and $\mathrm{CH}_{2} \mathrm{Cl}$ residues respectively. This interpretation is in agreement with the chemical shift and the coupling constant observed in the ${ }^{31} \mathrm{P}$-NMR spectrum of $\mathbf{5}$, which are both similar to those observed for the precursor. Finally, in the IR (ATR) spectrum, the broad absorption due to $\mathrm{OH}$ stretching in $\mathbf{4}$ had disappeared. The preparation of $\mathbf{5}$ is interesting, because 2-chloroethyl residues are typical of strong DNA alkylating agents and recently some $\mathrm{Pt}(\mathrm{II})$ and $\mathrm{Pt}(\mathrm{IV})$ complexes containing an analogous fragment were found active against pancreatic cancer cell lines. ${ }^{[11]}$

Interestingly, the observed reactivity was extended to alkylating agents other than 1,2-DCE. For instance, 4 was alkylated with benzyl bromide and with 1,4-dibromobutane under the same conditions, replacing 1,2-DCE with chloroform (Scheme 4).

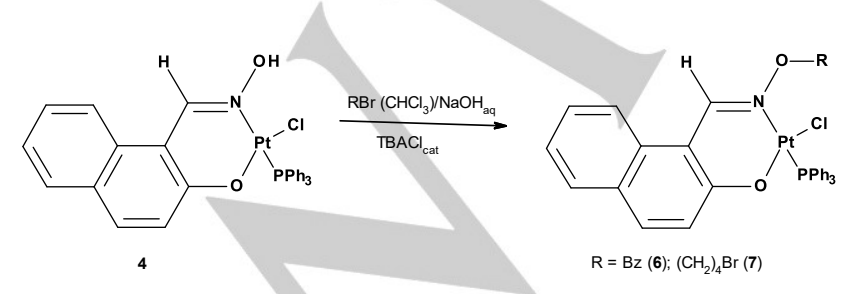

Scheme 4. O-alkylation of complex 4 by $\mathrm{RBr}$

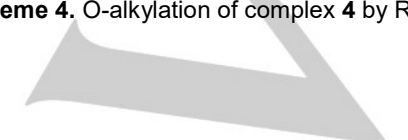

In these cases, the reactions were much faster, being complete in 2-7 $\mathrm{h}$ and only a slight excess of alkylating agent was necessary. Complexes 6 and 7 were recovered in good yields. In all the cases studied, the O-alkylation process was chemoselective and no products arising from substitution at the metal centre were observed.

\section{In vitro assays}

Complexes $\mathbf{3}$ and $\mathbf{4}$ were tested in vitro for their antiproliferative activity against three human tumor cell lines, HeLa (cervix adenocarcinoma), A2780 (ovarian carcinoma) and A2780cis (ovarian carcinoma cisplatin resistant). Data, expressed as $\mathrm{GI}_{50}$ $(\mu \mathrm{M})$, are reported in Table 2.

Table 2. Cell growth inhibition values in the presence of examined complexes and cisplatin as reference.

\begin{tabular}{cccc}
\hline \multirow{2}{*}{ Complex } & \multicolumn{3}{c}{ Cell Line $\mathrm{GI}_{50}{ }^{\mathrm{a}}(\mu \mathrm{M})$} \\
\cline { 2 - 4 } & HeLa & A2780 & A2780cis \\
\hline $\mathbf{3}$ & $3.53 \pm 0.99$ & $0.62 \pm 0.12$ & $2.73 \pm 0.21$ \\
$\mathbf{4}$ & $3.67 \pm 0.30$ & $0.94 \pm 0.28$ & $1.40 \pm 0.06$ \\
cisplatin & $1.42 \pm 0.32$ & $0.80 \pm 0.06$ & $7.01 \pm 0.26$ \\
\hline
\end{tabular}

[a] Values are the mean \pm SD of at least three independent experiments

Complexes $\mathbf{3}$ and $\mathbf{4}$ are able to exert a significant antiproliferative activity on both HeLa and A2780 cell lines. In particular, on HeLa cells the cytotoxicity induced by the new complexes appear quite lower with respect to that observed for cisplatin, while on A2780 cells comparable $\mathrm{GI}_{50}$ values were obtained. Notably, notwithstanding the similar effect on A2780 cells, sensitive toward cisplatin, on the corresponding resistant cell line, A2780cis, the cytotoxic capacity of $\mathbf{3}$ and $\mathbf{4}$ is significantly higher with respect to that of the drug, suggesting the possibility for these new $\mathrm{Pt}(\mathrm{II})$-based structures to overcome the resistance phenomenon. In this connection, $\mathbf{4}$ shows the most interesting behavior with a $\mathrm{GI}_{50}$ value on $\mathrm{A} 2780$ cis comparable to that obtained on A2780 cells. These results point to the new platinum(II) complexes bearing triphenylphosphine and bidentate oxime ligand as a lead moiety worth to be further developed for the synthesis of more efficacious $\mathrm{Pt}(\mathrm{II})$ complexes.

\section{Conclusions}

Two new platinum(II) complexes bearing $\mathrm{PPh}_{3}$ and bidentate oxime ligands were prepared in good yields from trans- $[\mathrm{PtCl}(\mu-$ $\left.\mathrm{Cl})\left(\mathrm{PPh}_{3}\right)\right]_{2}$ in the presence of silver acetate. Both complexes showed antiproliferative properties when tested against HeLa, A2780 and A2780cis cancer cell lines. In particular, they were able to circumvent resistance towards A2780cis cells, with 4 showing the best results. The mechanism of action is currently under investigation. The synthesized complexes reacted cleanly with alkylating agents in the presence of bases under PTC 
conditions, affording only the O-alkylation products. The reaction appears to be general, allowing the functionalization of the complex without affecting the coordination sphere of the bioactive platinum centre. This reactivity could be exploited to link the platinum center to fragments capable to bind to particular receptors, bioactive moieties or suitable nanoparticles, thus opening the way toward cooperation effects and drug delivery.

\section{Experimental Section}

Materials and general methods

All manipulations were performed under a dinitrogen atmosphere, if not otherwise stated. Solvents and liquid reagents were dried according to reported procedures ${ }^{[12]} .{ }^{1} \mathrm{H}-,{ }^{13} \mathrm{C}-,{ }^{31} \mathrm{P}$ - and ${ }^{195} \mathrm{Pt}$ NMR spectra were recorded with a Bruker "Avance DRX400" spectrometer, in $\mathrm{CDCl}_{3}$ solution if not otherwise stated. Chemical shifts were measured in ppm (ס) from TMS by residual solvent peaks for ${ }^{1} \mathrm{H}$ and ${ }^{13} \mathrm{C}$, from aqueous $\left(\mathrm{D}_{2} \mathrm{O}\right) \mathrm{H}_{3} \mathrm{PO}_{4}(85 \%)$ for ${ }^{31} \mathrm{P}$ and from aqueous $\left(\mathrm{D}_{2} \mathrm{O}\right)$ hexachloroplatinic acid for ${ }^{195} \mathrm{Pt}$. A sealed capillary containing $\mathrm{C}_{6} \mathrm{D}_{6}$ was introduced in the NMR tube to lock the spectrometer to the deuterium signal when nondeuterated solvents were used. FTIR spectra in solid phase were recorded with a Perkin-Elmer "Spectrum One" spectrometer, equipped with an ATR accessory. Elemental analyses $(\mathrm{C}, \mathrm{H}, \mathrm{N})$ were performed at Dipartimento di Scienze e Tecnologie Chimiche, Università di Udine and at Dipartimento di Chimica e Chimica Industriale, Università di Pisa. Trans- $\left[\mathrm{Pt}(\mu-\mathrm{Cl}) \mathrm{Cl}\left(\mathrm{PPh}_{3}\right)\right]_{2}{ }^{[7]}$ was prepared according to a reported procedure. Aldoxime ligands 1-2 (Figure 1) were prepared by a slight modification of a described procedure. ${ }^{[6]}$ Hydroxylamine hydrochloride $\left(\mathrm{NH}_{2} \mathrm{OH} \cdot \mathrm{HCl}\right)(99 \%$, Carlo Erba) and silver acetate $(98 \%$, Sigma Aldrich) were used without further purification.

In the text, the following abbreviations were used: 1,2-dichloroethane (1,2-DCE), tetrabutylammonium chloride (TBACl).

General procedure for the synthesis of bidentate oxime complexes

A Schlenk tube equipped with a magnetic stirrer was charged with $\mathrm{Pt}(\mu-$ $\left.\mathrm{Cl}) \mathrm{Cl}\left(\mathrm{PPh}_{3}\right)\right]_{2}(0.300-0.500 \mathrm{~g})$, the suitable bidentate oxime (oxime/Pt = 1.03 molar ratio), silver acetate $(\mathrm{Ag}(\mathrm{OAc}) / \mathrm{oxime}=1.00$ molar ratio $)$ and 1,2-DCE. The mixture was shielded from light and stirred at $25{ }^{\circ} \mathrm{C}$. A yellow solution was obtained and a colorless solid formed almost immediately. The suspension was stirred until the maximum conversion was reached $\left({ }^{31} \mathrm{P}-\mathrm{NMR}, 2 \mathrm{~h}\right)$, then was filtered on a short package of celite. The liquid phase was concentrated under vacuum up to one third of the original volume and then treated with heptane. The yellow solid precipitated was filtered, washed with heptane and dried under vacuum.

For each of the bidentate complexes, the oxime used, the $\%$ isolated yield and the characterization are reported.

$\left[\mathrm{Pt}(\mathrm{Cl})\left(\mathrm{PPh}_{3}\right)\left\{\left(\mathrm{K}^{2}-\mathrm{N}, \mathrm{O}\right)-\left[1(\mathrm{O})-2\left(\mathrm{C}(\mathrm{Me}) \mathrm{N}(\mathrm{OH}) \mathrm{C}_{10} \mathrm{H}_{6}\right]\right\}\right]\right.$ (3)

Oxime 1; $70 \%$. $\mathrm{C}_{30} \mathrm{H}_{25} \mathrm{CINO}_{2} \mathrm{PPt} \cdot 1.5 \mathrm{H}_{2} \mathrm{O}$ Anal. Calc.: C $50.0, \mathrm{H} 3.9, \mathrm{~N}$ 1.9\%. Exp.: C 50.0, H 4.0, N 1.7 \%. IR (ATR, $\tilde{v}, \mathrm{~cm}^{-1}$ ): 3257; 3053; 2960; $1625 ; 1593 ; 1570 ; 1544 ; 1501 ; 1481 ; 1456 ; 1435 ; 1418 ; 1398 ; 1372$; 1338; 1260; 1245; 1188; 1133; 1099; 1021; 998; 975; 900; 868; 796;
747; 710. ${ }^{1} \mathrm{H}$ NMR: 10.81 (s, 1H, Oㅡ); 7.87-7.82 (m, 6H, $\mathrm{H}_{\text {arom }} \mathrm{PPh}_{3}$ ); 7.76-7.71 (m, 2H, $\mathrm{H}_{\text {arom }}$ ); 7.54-7.44 (m, 9H, $\left.\mathrm{H}_{\text {arom }} \mathrm{PPh}_{3}\right)$, 7.35-7.31 (m, $1 \mathrm{H}$, $\mathrm{H}_{\text {arom }}$ ); 7.08 (d, $\left.1 \mathrm{H}, \mathrm{J}=8.7 \mathrm{~Hz}, \mathrm{H}_{\text {arom }}\right) ; 6.82-6.79\left(\mathrm{~m}, 1 \mathrm{H}, \mathrm{H}_{\text {arom }}\right) ; 6.59$ (d, $1 \mathrm{H}$, $\mathrm{J}=8.7 \mathrm{~Hz}, \mathrm{H}_{\text {arom }}$ ); 2.60 (s, 3H, $\mathrm{CH}_{3}$ ). ${ }^{13} \mathrm{C}$ NMR: 158.3; 134.8 (d, J=10.7 $\mathrm{Hz}$ ); 131.1; 128.5 (d, J=11.2 Hz); 128.4; 128.3; 128.2; $127.7 ; 127.5125 .9$ (d, J=74.4 Hz); 125.5; 124.3; 116.9; 116.4; 77.2; 15.06. ${ }^{31} \mathrm{P}$ NMR: 6.73 $\left(\mathrm{J}_{\mathrm{P}-\mathrm{Pt}}=3891 \mathrm{~Hz}\right) .{ }^{195} \mathrm{Pt}$ NMR:-2938 $\left(\mathrm{J}_{\mathrm{P}-\mathrm{Pt}}=3891 \mathrm{~Hz}\right)$.

$\left[\mathrm{Pt}(\mathrm{Cl})\left(\mathrm{PPh}_{3}\right)\left\{\left(\mathrm{K}^{2}-\mathrm{N}, \mathrm{O}\right)-\left[1\left(\mathrm{CHN}(\mathrm{OH})-2(\mathrm{O}) \mathrm{C}_{10} \mathrm{H}_{6}\right]\right\}\right](4)\right.$

Oxime 2; $89 \% . \mathrm{C}_{29} \mathrm{H}_{23} \mathrm{CINO}_{2} \mathrm{PPt} \cdot \mathrm{H}_{2} \mathrm{O}$. Anal. Calc.: C 50.0, H 3.6, N 2.0 \%; Exp.: C 49.8, H 3.2, N 2.1 \%. IR (ATR, $\tilde{v}, \mathrm{~cm}^{-1}$ ): 3237; 3055; 2963; 2903; 2860; 1628; 1599; 1548; 1515; 1482; 1455; 1435; 1424; 1405; 1354; 1332; 1298; 1260; 1189; 1092; 1017; 947; 865; 797; 745; 707; 692. ${ }^{1} \mathrm{H}$ NMR: 10.53 (s, 1H, O트); 9.21 (d, 1H, J=9.6 Hz, CㅌN); 7.92 (d, 1H, $\left.\mathrm{J}=9.0 \mathrm{~Hz}, \mathrm{H}_{\text {arom }}\right) ; 7.84-7.79\left(\mathrm{~m}, 7 \mathrm{H}, \mathrm{H}_{\text {arom }}+\mathrm{H}_{\text {arom }} \mathrm{PPh}_{3}\right) ; 7.64(\mathrm{~d}, 1 \mathrm{H}, \mathrm{J}=7.9$ $\left.\mathrm{Hz}, \mathrm{H}_{\text {arom }}\right) ; 7.57-7.48\left(\mathrm{~m}, 11 \mathrm{H}, \mathrm{H}_{\text {arom }}+\mathrm{H}_{\text {arom }} \mathrm{PPh}_{3}\right) ; 6.41(\mathrm{~d}, 1 \mathrm{H}, \mathrm{J}=9.0 \mathrm{~Hz}$,

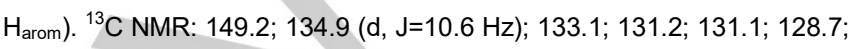
128.2 (d, J=11.3 Hz); 127.9; 127.8; 127.5 (d, J=67 Hz); 127.4; 127.3; 123.0; 122.7; 119.5. ${ }^{31} \mathrm{P}$ NMR: 7.28 (J $\left.\mathrm{J}_{\mathrm{P}-\mathrm{Pt}}=3829 \mathrm{~Hz}\right) .{ }^{195} \mathrm{Pt}$ NMR: -2909 $\left(\mathrm{J}_{\mathrm{P}-\mathrm{Pt}}=3829 \mathrm{~Hz}\right)$.

O-Alkylation of bidentate oxime complexes

$\left[\mathrm{Pt}(\mathrm{Cl})\left(\mathrm{PPh}_{3}\right)\left\{\left(\mathrm{K}^{2}-\mathrm{N}, \mathrm{O}\right)-\left[1\left(\mathrm{CHN}\left(\mathrm{OCH}_{2} \mathrm{CH}_{2} \mathrm{Cl}\right)-2(\mathrm{O}) \mathrm{C}_{10} \mathrm{H}_{6}\right]\right\}\right]\right.$ (5)

A Shlenk tube equipped with a magnetic stirrer was charged with a 1,2DCE solution of $4(69.9 \mathrm{mg}, 0.103 \mathrm{mmol}$ in $10.0 \mathrm{ml})$, a $0.02 \mathrm{M}$ solution of $\mathrm{NaOH}$ in water $(10.0 \mathrm{~mL})$ and a catalytic amount of tetrabutylammonium chloride (TBACl, $5 \mathrm{~mol}$ \%). The mixture was stirred at room temperature $\left(25{ }^{\circ} \mathrm{C}\right)$ and the complete conversion of the precursor into a single product was checked spectroscopically $\left({ }^{31} \mathrm{P} N M R, 24 \mathrm{~h}\right)$. After separating the two phases, the aqueous phase was extracted with portions of 1,2DCE $(3 \times 10 \mathrm{~mL})$. The collected organic phases were dried over anhydrous $\mathrm{Na}_{2} \mathrm{SO}_{4}$, filtered and concentrated up to $10 \mathrm{~mL}$. The addition of heptane $(20 \mathrm{~mL})$ caused the precipitation of an orange solid, which was filtered, washed with heptane and dried under vacuum $(40.5 \mathrm{mg}$, $53 \%$ isolated yield). $\mathrm{C}_{31} \mathrm{H}_{26} \mathrm{Cl}_{2} \mathrm{NO}_{2} \mathrm{PPt} \cdot \mathrm{H}_{2} \mathrm{O}$. Anal. Calc.: C 49.0, H 3.7, N 1.8 \%; Exp.: C 49.4, H 3.7, N 1.6 \%. IR (ATR, v , cm ${ }^{-1}$ ): 2964; 2906; 1619; $1602 ; 1541 ; 1507 ; 1481 ; 1429 ; 1407 ; 1335 ; 1259 ; 1084 ; 1015 ; 946 ; 863$; 796; 753; 710. ${ }^{1} \mathrm{H}$ NMR: $9.42\left(\mathrm{~d}, 1 \mathrm{H}, \mathrm{H}_{\text {arom }}\right) ; 7.89-7.79(\mathrm{~m}, 8 \mathrm{H}, \mathrm{C} \underline{\mathrm{HN}}+$ $\mathrm{H}_{\text {arom }}$ ); 7.63 (d, 2H, $\mathrm{H}_{\text {arom }}$ ); 7.55-7.46 (m, 13H, $\mathrm{H}_{\text {arom }}$ ); 7.24 (d, $1 \mathrm{H}, \mathrm{H}_{\text {arom }}$ ); 4.70 (t, 2H, OC${ }_{2}$ ); 3.83 (t, 2H, $\underline{\mathrm{C}}_{2} \mathrm{Cl}$ ). ${ }^{13} \mathrm{C} \mathrm{NMR}: 151.0 ; 135.0$ (d, J=10.3 $\mathrm{Hz}$ ); 133.6; 131.0; 128.3 (d, J=80.5 Hz); 128.2 (d, J=10.9 Hz); 123.1; 119.5; 76.4; 41.1. ${ }^{31} \mathrm{P}$ NMR: $6.01\left(\mathrm{~J}_{\mathrm{P}-\mathrm{Pt}}=3807 \mathrm{~Hz}\right) .{ }^{195} \mathrm{Pt}$ NMR: $-2849\left(\mathrm{~J}_{\mathrm{P}-}\right.$ $\mathrm{Pt}=3807 \mathrm{~Hz})$.

$\left[\mathrm{PtCl}\left(\mathrm{PPh}_{3}\right)\left\{\left(\kappa^{2}-\mathrm{N}, \mathrm{O}\right)-\left[1\left(\mathrm{CHN}(\mathrm{OR})-2(\mathrm{O}) \mathrm{C}_{10} \mathrm{H}_{6}\right]\right\}\right]\right.$ General procedure.

A Shlenk tube equipped with a magnetic stirrer was charged with a solution of 4 in $\mathrm{CHCl}_{3}$ (about $0.15 \mathrm{mmol}$ in $\left.10.0 \mathrm{~mL}\right), \mathrm{RBr}(\mathrm{RBr} / \mathrm{Pt}=1.3$ molar ratio), a catalytic amount ( $5 \mathrm{~mol}-\%)$ of $\mathrm{TBACl}$ and a $0.02 \mathrm{M}$ solution of $\mathrm{NaOH}$ in water $(10.0 \mathrm{~mL})$. The mixture was stirred at room temperature $\left(25^{\circ} \mathrm{C}\right)$ and the complete conversion of the precursor was 
checked spectroscopically $\left({ }^{31} \mathrm{P}\right.$ NMR, 2-5 h). After separating the two phases, the aqueous phase was extracted with portions of $\mathrm{CHCl}_{3}(3 \times 10$ $\mathrm{mL}$ ). The collected organic phases were dried over anhydrous $\mathrm{Na}_{2} \mathrm{SO}_{4}$, filtered and concentrated up to $10 \mathrm{~mL}$. The addition of heptane $(20 \mathrm{~mL})$ caused the precipitation of an orange solid, which was filtered, washed with heptane and dried under vacuum. For each O-alkylated complex the alkyl bromide used, the isolated yield and the characterization are reported:

\section{$\left[\mathrm{PtCl}\left(\mathrm{PPh}_{3}\right)\left\{\left(\mathrm{K}^{2}-\mathrm{N}, \mathrm{O}\right)-\left[1\left(\mathrm{CHN}(\mathrm{OBz})-2(\mathrm{O}) \mathrm{C}_{10} \mathrm{H}_{6}\right]\right\}\right](6): \mathrm{BzBr}, 50 \%\right.$}

IR $\left(\tilde{v}, \mathrm{~cm}^{-1}\right): 3055 ; 2963 ; 1619 ; 1599 ; 1533,1434,1332,1300,1189$; 1097; 1016; 949; 799, 743; 692. ${ }^{1} \mathrm{H}$ NMR: 9.06 (d, 1H, J=8.4Hz, CHN); 7.94-7.85 (m, 4H, $\mathrm{HPPh}_{3}$ ); 7.65 (m, 2H, HAr); 7.62-7.46 (m, 14H, HAr + $\left.\mathrm{HPPh}_{3}\right)$; 7.33-7.35 (m, 2H, HAr); 7.27-7.20 (m, 1H, HAr); $6.27(\mathrm{~d}, 1 \mathrm{H}$, HAr); 5.45 ppm (s, $\left.2 \mathrm{H}, \mathrm{CH}_{2} \mathrm{Ph}\right) .{ }^{13} \mathrm{C}$ NMR: 163.5, 151.4, 151.3, 135.4 135.0, (d, J=11 Hz), 134.9, 133.3, 131.0, 129.9, 128.7, 128.5, 128.3, $128.1(\mathrm{~d}, \mathrm{~J}=10 \mathrm{~Hz}), 128.4(\mathrm{~d}, \mathrm{~J}=67 \mathrm{~Hz}), 127.6,123.3,122.9,119.4$, 105.7, 79.7. ${ }^{31}$ P NMR: 6.47 (J=3783 Hz). ${ }^{195} \mathrm{Pt}$ NMR: $-2843(\mathrm{~J}=3783 \mathrm{~Hz})$.

$\left[\mathrm{PtCl}\left(\mathrm{PPh}_{3}\right)\left\{\left(\mathrm{K}^{2}-\mathrm{N}, \mathrm{O}\right)-\left[1\left(\mathrm{CHN}\left(\mathrm{O}\left(\mathrm{CH}_{2}\right)_{4} \mathrm{Br}\right)-2(\mathrm{O}) \mathrm{C}_{10} \mathrm{H}_{6}\right]\right\}\right] \quad(7): \mathrm{Br}\left(\mathrm{CH}_{2}\right)_{4} \mathrm{Br}\right.$, $71 \%$.

$\mathrm{C}_{33} \mathrm{H}_{30} \mathrm{BrClNO}_{2}$ PPt. Anal. Calc.: C 48.7, H 3.7, N 1.7 \%; Exp.: C 48.7, H 3.4, N $2.0 \%$. IR ( $\left(\tilde{v}, \mathrm{~cm}^{-1}\right): 3055,2943,1615,1596,1533,1504,1435$, 1389, 1323, 1256, 1098, 1032, 961, 900, 868, 837, 746, 691. ${ }^{1} \mathrm{H}$ NMR: $9.27(\mathrm{~d}, 1 \mathrm{H}, \mathrm{J}=8.6 \mathrm{~Hz}, \underline{\mathrm{CHN}}) ; 7.88-7.83\left(\mathrm{~m}, 7 \mathrm{H}, \mathrm{H}_{\mathrm{Ar}}\right) ; 7.63(\mathrm{~d}, 1 \mathrm{H}, \mathrm{J}=7.7$ $\left.\mathrm{Hz}, \mathrm{H}_{\mathrm{Ar}}\right) ; 7.59-7.44\left(\mathrm{~m}, 11 \mathrm{H}, \mathrm{H}_{\mathrm{Ar}}\right) ; 7.28\left(\mathrm{~m}, 1 \mathrm{H}, \mathrm{H}_{\mathrm{Ar}}\right) ; 6.26(\mathrm{~d}, 1 \mathrm{H}, \mathrm{J}=7.7$ $\mathrm{Hz}, \mathrm{H}_{\mathrm{Ar}}$ ); 4.45 (t, $\left.2 \mathrm{H}, \mathrm{J}=6.5 \mathrm{~Hz}, \mathrm{NOCH}_{2}\right) ; 3.53\left(\mathrm{t}, 2 \mathrm{H}, \mathrm{J}=6.5 \mathrm{~Hz}, \mathrm{CH}_{2} \mathrm{Br}\right.$ ); 2.15 (quint, $2 \mathrm{H}, \mathrm{J}=6.5 \mathrm{~Hz}, \mathrm{NOCH}_{2} \mathrm{CH}_{2}$ ); 1.97 (quint, $2 \mathrm{H}, \mathrm{J}=6.5 \mathrm{~Hz}$, $\left.\mathrm{CH}_{2} \mathrm{CH}_{2} \mathrm{Br}\right) .{ }^{13} \mathrm{C}$ NMR: $163.6,150.6,150.5,135.0(\mathrm{~d}, \mathrm{~J}=11 \mathrm{~Hz}), 134.8$, 133.2, 131.0, 128.8, $128.2(\mathrm{~d}, \mathrm{~J}=10 \mathrm{~Hz}), 127.6(\mathrm{~d}, \mathrm{~J}=64 \mathrm{~Hz}), 127.7$, 127.4, 123.0, 119.4, 106.0, 76.6, 33.9, 29.5, 26.6. ${ }^{31} \mathrm{P}$ NMR: 6.45 $(\mathrm{J}=3792 \mathrm{~Hz}) .{ }^{195} \mathrm{Pt} \mathrm{NMR}:-2843(\mathrm{~J}=3792 \mathrm{~Hz})$.

\section{Inhibition Growth Assay}

HeLa (human cervix adenocarcinoma cells) were grown in Nutrient Mixture F-12 [HAM] (Sigma Chemical Co.); A2780 (human ovarian carcinoma) and A2780cis (human ovarian carcinoma cisplatin-resistant) were grown in RPMI 1640 (Sigma Chemical Co.). $1.5 \mathrm{~g} / \mathrm{L} \mathrm{NaHCO} 3,10 \%$ heat-inactivated fetal calf serum (Invitrogen), $100 \mathrm{U} / \mathrm{mL}$ penicillin, 100 $\mu \mathrm{g} / \mathrm{mL}$ streptomycin, and $0.25 \mu \mathrm{g} / \mathrm{mL}$ amphotericin B (Sigma Chemical Co.) were added to the media. The cells were cultured at $37^{\circ} \mathrm{C}$ in a moist atmosphere of 5 vol.-\% carbon dioxide in air. HeLa cells $\left(4 \times 10^{4}\right)$, A2780 $\left(2.5 \times 10^{4}\right)$ or A2780cis $\left(2.5 \times 10^{4}\right)$ were seeded into each well of a 24well cell culture plate. After incubation for $24 \mathrm{~h}$, various concentrations of the test agents were added to the complete medium and incubated for a further $72 \mathrm{~h}$. Stock solutions of new complexes were made in dimethylsulfoxide at $20 \mathrm{mM}$ concentration and then diluted with complete medium in such a way that the final amount of solvent in each well did not exceed 0.5 vol.-\%. Cisplatin was dissolved in 0.9 wt.- $\% ~ \mathrm{NaCl}$. A Trypan blue assay was performed to determine cell viability. Cytotoxicity data were expressed as $\mathrm{GI}_{50}$ values, i.e., the concentration of the test agent inducing $50 \%$ reduction in cell number compared with control cultures.

\section{$X$-Ray determinations}

Crystals of 4 were selected at room temperature (296 K), glued to glass fibers and analyzed with a Bruker Smart Breeze CCD diffractometer. Table 3 summarizes the lattice parameters and the space group. Intensity data were collected in the range of $2 \theta$ angles reported in Table 3. After correction for Lorentz and polarization effects and for absorption, the structure solution was obtained using the direct methods contained in SHELXS program. ${ }^{[13]}$ The hydrogen of oxime hydroxyl residue was found in the difference Fourier map, while the other hydrogen atoms were introduced in calculated positions. The final reliability factors of the refinement procedure, done using SHELXL program, ${ }^{[14]}$ are listed in Table 3. Other control calculations were performed with the programs contained in the WINGX suite. ${ }^{[15]}$

CCDC 1590522 for $\mathbf{4}$ contains the supplementary crystallographic data for this paper. These data can be obtained free of charge from The Cambridge Crystallographic Data Centre.

Table 3. Crystal data and structure refinement for complex 4.

\begin{tabular}{|c|c|c|}
\hline Compound & 4 & \\
\hline Empirical formula & $\mathrm{C}_{29} \mathrm{H}_{23} \mathrm{CINO}_{2} \mathrm{PPt}$ & \\
\hline Formula weight & 678.99 & \\
\hline Temperature & $296(2) \mathrm{K}$ & \\
\hline Wavelength & $0.71073 \AA$ & \\
\hline Crystal system & Monoclinic & \\
\hline Space group & $\mathrm{C} 2 / \mathrm{c}$ & \\
\hline Unit cell dimensions & $\begin{array}{c}a=17.0248(7) \AA \\
b=9.7147(4) \AA \\
c=30.9507(17) \AA\end{array}$ & $\begin{array}{c}\alpha=90^{\circ} . \\
\beta=101.871(2)^{\circ} \\
y=90^{\circ} .\end{array}$ \\
\hline Volume & $5009.5(4) \AA^{3}$ & \\
\hline Z & & \\
\hline Density (calculated) & $1.801 \mathrm{Mg} / \mathrm{m}^{3}$ & \\
\hline Absorption coefficient & $5.800 \mathrm{~mm}^{-1}$ & \\
\hline$F(000)$ & 2640 & \\
\hline Crystal size & $0.250 \times 0.204 \times 0.030 \mathrm{~mm}^{3}$ & \\
\hline $\begin{array}{l}\text { Theta range for data } \\
\text { collection }\end{array}$ & 2.894 to $33.732^{\circ}$. & \\
\hline Index ranges & $\begin{array}{l}-26<=\mathrm{h}<=26,-15<=\mathrm{k}<=12 \\
-46<=\mathrm{k}<=37\end{array}$ & \\
\hline Reflections collected & 33996 & \\
\hline $\begin{array}{l}\text { Independent } \\
\text { reflections }\end{array}$ & $9433[R($ int $)=0.0382]$ & \\
\hline $\begin{array}{l}\text { Completeness to theta } \\
=25.242^{\circ}\end{array}$ & $99.8 \%$ & \\
\hline Refinement method & $\begin{array}{l}\text { Full-matrix least-squares } \\
\text { on } \mathrm{F}^{2}\end{array}$ & \\
\hline $\begin{array}{l}\text { Data / restraints / } \\
\text { parameters }\end{array}$ & $9433 / 0 / 316$ & \\
\hline Goodness-of-fit on $\mathrm{F}^{2}$ & 0.961 & \\
\hline $\begin{array}{l}\text { Final } R \text { indices } \\
{[\mid>2 \text { sigma }(I)]}\end{array}$ & $\begin{array}{l}\mathrm{R} 1=0.0383, \mathrm{wR} 2= \\
0.0818\end{array}$ & \\
\hline $\mathrm{R}$ indices (all data) & $\begin{array}{l}\mathrm{R} 1=0.0678, w R 2= \\
0.0915\end{array}$ & \\
\hline Extinction coefficient & $\mathrm{n} / \mathrm{a}$ & \\
\hline $\begin{array}{l}\text { Largest diff. peak and } \\
\text { hole }\end{array}$ & 1.628 and -0.879 e..$\AA^{-3}$ & \\
\hline
\end{tabular}




\section{Acknowledgements}

The authors thank the Università di Pisa (Fondi di Ateneo 2016) and MIUR (PRIN 2015, "Design of Innovative Metal-Ligand Systems for Catalysis and Energy Applications") for financial support and Interuniversity Consortium CHEMICAL REACTIVITY and CATALYSIS (CIRCC). S. S. is grateful to the financial support provided by Università di Pisa-Progetti di Ricerca di Ateneo 2017-'Composti di metalli di transizione come possibili agenti antitumorali' (PRA_2017_25). L. D. V. is grateful to the financial support provided by Dipartimento di Scienze del Farmaco-Università di Padova-Progetti di Ricerca di Dipartimento PRID 2017- "An in depth investigation on novel Ptbased agents to shed light on cancer resistance mechanims" and thanks the Consorzio Interuniversitario di Ricerca in Chimica dei Metalli nei Sistemi Biologici (CIRCMSB). Thanks are due to $\mathrm{Dr}$. D. Scittarelli for preliminary experiments.

Keywords: platinum - antitumor agents - oxime ligands • functionalization

[1] B. Rosenberg, L. Van Camp, T. Crigas, Nature 1965, 205, 698-699.

[2] T. C. Johnstone, K. Suntharalingam, S. J. Lippard, Chem. Rev. 2016 116, 3436-3486.

[3] a) D. Belli Dell' Amico, M. Colalillo, L. Labella, F. Marchetti, S. Samaritani, Inorg. Chim. Acta 2018, 470, 181-186; b) D. Belli Dell' Amico, L. Bellucci, L. Labella, F. Marchetti, S. Samaritani, Polyhedron 2016, 119, 403-411; c) D. Belli Dell' Amico, L. Labella, F. Marchetti, S Samaritani, G. A. Hernández-Fuentes, A. N. García-Argáez, L. Dalla Via, Polyhedron 2016, 119, 396-402; d) L. Dalla Via, A. N. GarcíaArgáez, E. Agostinelli, D. Belli Dell'Amico, L. Labella, S. Samaritani, Bioorg. Med. Chem. 2016, 24, 2929-2937; e) D. Belli Dell'Amico, L. Dalla Via, A. N. García-Argáez, L. Labella, F. Marchetti, S. Samaritani Polyhedron 2015, 85, 685-689; f) L. Nierzwicki, M. Wieczor, V. Censi, M. Baginski, L. Calucci, S. Samaritani, J. Czub, C. Forte, Phys.Chem.Chem.Phys. 2015, 17, 1458-1468; g) L. Dalla Via, A. N. García-Argáez, A. Adami, S. Grancara, P. Martinis, A. Toninello, D.
Belli Dell'Amico, L. Labella, S. Samaritani, Bioorg. Med. Chem. 2013 21, 6965-6972; h) D. Belli Dell'Amico, C. Broglia, L. Labella, F. Marchetti, D. Mendola, S. Samaritani, Inorg. Chim. Acta 2013, 395 181-188; i) M. Á. Medrano, A. Á. Ivarez-Valde's, J. Perles, J. LloretFillol, S. Muñoz-Galván, A. Carnero, C. Navarro-Ranninger, A. G Quiroga, Chem. Commun. 2013, 49, 4806-4808; j) A.G. Quiroga, F.J. Ramos-Lima, A. Alvarez-Valdés, M. Font-Bardía, A. Bergamo, G. Sava, C. Navarro-Ranninger, Polyhedron 2011, 30,1646-1650; k) F. J. Ramos-Lima, A. G. Quiroga, B. Garcia-Serrelde, F. Blanco, A. Carnero C. Navarro-Ranninger, J. Med. Chem. 2007, 50, 2194-2199; I) F. J. Ramos-Lima, A. G. Quiroga, J. M. Pérez, M. Font-Bardía, X Solans, C Navarro-Ranninger, Eur. J. Inorg. Chem. 2003, 1591-1598.

[4] a) V. Y. Kukushkin, A. J. L. Pombeiro, Coord. Chem. Rev. 1999, 181 147-175; b) A. K. Yatsimirsky, G. M. Kazankov, A. D. Ryabov, J. Chem Soc., Perkin Trans. 2 1992, 1295-1300; c) A. M. Afanasenko, E. Y. Bulatov, T. G. Chulkova, M. Haukka, F. M. Dolgushin, Trans. Met Chem. 2016, 41, 387-392; d) E. Y. Bulatov, T. G. Chulkova, M. Haukka V. Y. Kukushkin, J. Chem. Crystallogr. 2012, 42, 352-355; e) S. U Pandya, K. C. Moss, M. R. Bryce, A. S. Batsanov, M. A. Fox, V. Jankus, H. A. Al Attar, A. P. Monkman, Eur. J. Inorg. Chem. 2010 1963-1972; f) S. Otto, A. Chanda, P. V. Samuleev, A. D. Ryabov, Eur. J. Inorg. Chem. 2006, 2561-2565; g) V. Y. Kukushkin, V. K. Belsky, E. A. Aleksandrova, V. E. Konovalov, G. A. Kirakosyan, Inorg. Chem. 1992, 31, 3836-3840.

[5] a) Y. Y. Scaffidi-Domianello, K. Meelich, M. A. Jakupec, V. B. Arion, V. Y. Kukushkin, M. Galanski, B. K. Keppler, Inorg. Chem. 2010, 49, 5669-5678; b) A. G. Quiroga, L. Cubo, E. de Blas, P. Aller, C. NavarroRanninger, J. Inorg. Biochem. 2007, 101, 104-110.

[6] C. B. Aakeröy, A. S. Sinha, RSC Advance 2013, 3, 8168-8171.

D. Belli Dell'Amico, L. Labella, F. Marchetti, S. Samaritani, Dalton Trans. 2012, 41, 1389-1396.

[8] Y. Y. Scaffidi-Domianello, A. A. Legin, M. A. Jakupec, A. Roller, V. Y. Kukushkin, M. Galanski, B. K. Keppler, Inorg. Chem. 2012, 51, 7153 7163.

[9] H. P. Varbanov, D. Ortiz, D. Höfer, L. Menin, M. Galanski, B. K Keppler, P. J. Dyson, Dalton Trans. 2017, 46, 8929-8932.

[10] S. F. Kaplan, V. Y. Kukushkin, S. Shova, K. Suwinska, G. Wagner, A. J. L. Pombeiro, Eur. J. Inorg. Chem., 2001, 1031-1038.

[11] a) S. Karmakar, S. Chatterjee, K. Purkait, A. Mukherjee, Dalton Trans. 2016, 45, 11710-11722. b) S. Karmakar, K. Purkait, S. Chatterjee, A Mukherjee, Dalton Trans., 2016, 45, 3599-3615.

[12] W. L. F. Armarego, D. D. Perrin in Purification of Laboratory Chemicals Butterworth-Heinemann, 1996.

[13] G. M. Sheldrick, SHELXS. Version 2014/7 2013, Georg-AugustUniversität Göttingen, Göttingen, Germany.

[14] G.M. Sheldrick, SHELXL (Release 97-2) 1998, University of Göttingen, Göttingen, Germany.

[15] L.J. Farrugia, J. Appl. Crystallogr. 1999, 32, 837-838. 
WILEY-VCH

\section{FULL PAPER}

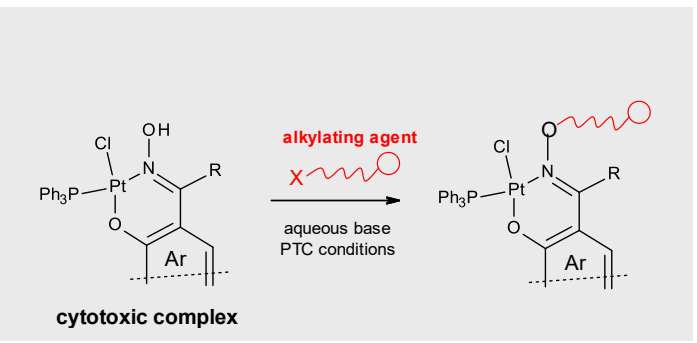

\section{Anticancer complexes}

Daniela Belli Dell' Amico, Marialuigia Colalillo, Lisa Dalla Via, Martina Dell' Acqua, Aida N. Garcia-Argáez, Mariafrancesca Hyeraci, Luca Labella, Fabio Marchetti and Simona Samaritani*

Page No. - Page No.

Synthesis and reactivity of cytotoxic platinum(II) complexes of bidentate oximes: a step towards the functionalization of bioactive complexes 